WARSZAWA 2000 Vol. 9

\title{
Stanisław Osiński
}

\section{STRUCTURAL CHANGES IN INDUSTRY IN THE POLISH EASTERN BORDER REGIONS BETWEEN 1985 AND 1997}

The integration processes taking place in Western Europe, as well as the political and economic transformations in Central and Eastern Europe caused a rise in interest in the issues of development in border regions. The Polish border regions are usually characterised by (among other things) a smaller population density and a lower number of urban areas than in comparison to central regions as well as weaker economic development and especially the level of industrialisation. The area along the eastern frontier of the country occupy a different position to the other border region and they are often derogatorily termed as the "Eastern Wall". And yet it is quite possible to come across even harsher descriptions of the region e.g. "the eastern zone of retarded development of civilization" (Mokrzyc, 1998).

Economic and political changes in Poland, its aspirations for full integration with the European Union as well as the liberalisation of social relations and administrative rules on border crossing, has caused an increase in the mobility of the people, and increase in mass international journeys as well as new and better chances for the development of border regions. According to M. Rościszewski (1999, p. 59) "The border region of Poland that was once known as the "Eastern Wall" and was undergoing depopulation and economic stagnation, is now slowly becoming a 'gate' for Poland and Europe to regions in the East, as well as a 'gate' for those eastern regions in their contact with the West". This is why M. Rościszewski proposed to call the eastern part of Poland as "The Eastern Zone of Economic Activity" (EZEA) (Rościszewski, 1997, 1999).

In the socialist economy, industry belonged to one of the privileged sectors. Due to the transformations that were occurring in Poland, it became necessary to increase the competitiveness of Polish industry through structural changes like ownership, size and sector structure.

The analysis of structural changes in industry was carried out with the help of statistical data ${ }^{1}$ on the number of employees working in industry.

${ }^{1}$ General statistical data for industry is obtained from the Statistical Annals of Industry (1986-1999), whilst the structural information on employment comes from 1985 industrial listings and provincial materials from the Central Statistical Office. 
Research was limited to seven of the former voivodships ${ }^{2}$, situated on the eastern border of Poland. Going from North to South, these were: the Suwałki, Białystok, Biała Podlaska, Chełm, Zamość, Przemyśl, and Krosno voivodships. The studied region had an area of $46,878 \mathrm{~km}^{2}$ (15\% of the total area of Poland) and was characterised by a smaller population density (3164.2 thousand inhabitants in 1997, 67.1 people per square kilometre, $8.2 \%$ of the total population) and a lower level of urbanisation (1455.6 thousand people in 78 cities; level of urbanisation $-46 \%$; $6.1 \%$ of total urban population) than the rest of Poland. Białystok was (and still is) the largest city of the region (282.5 thousand inhabitants in 1997) and at the same time its main industrial district (Dziakowska, Osiński, 1999).

From 1985 to 1997 the number of employees working in industry (as in the rest of the country) decreased - from 242.8 thousand to 188.2 thousand people (23.3\%). The studied region belongs to one of the least industrialised areas in Poland. In 1997 the area concentrated 5.0\% of workers employed in industry, $4.3 \%$ of the value of fixed goods, $4.2 \%$ of investment expenditure and it provided $3.8 \%$ of the total sold industrial production. In $199746.9 \%$ of the country's bus production, $25.8 \%$ of Poland's natural gas production, $16.4 \%$ of woollen textiles and wool substitutes made in Poland, $15.2 \%$ of crude oil production, $14.9 \%$ of manufactured cigarettes, $13.6 \%$ of Polish butter, $13.4 \%$ plywood, $13.3 \%$ of processed meat and $12.7 \%$ of cement made in Poland came from this area.

\section{OWNERSHIP STRUCTURE OF INDUSTRIAL ENTERPRISES}

One of the consequences of the transformation from a centrally controlled economy to a market economy, is the process of privatisation and the consequent rise of the private sector. After a couple of decades in a socialist economy, the Polish private sector was relatively insignificant and was reduced to mainly small enterprises employing - as a rule - not more than five workers. Until 1980 these enterprises were discriminated against in various ways and, due to doctrinal factors, their development was intentionally thwarted. They were seen as potential sources from which a capitalist economy could be reborn (Misztal, 1993).

The economic crisis that began to come to light in the second half of the seventies and the growing lack of consumption goods in the internal market led to the softening of some of the administrative laws and rules that prevented the development of private industry. The economic and social crisis in 1980-1981 forced the authorities to, among other things, allow for the

\footnotetext{
${ }^{2}$ Since the 1st of January 1999 a new administrative division has taken place in Poland. The eastern border regions are now part of considerably larger administrative units than before.
} 
creation of small, private enterprises. Thus, limited changes in the ownership structure of Polish industry occurred as early as the eighties. These changes involved the lifting of legal and administrative barriers, what in effect meant the simplification of bureaucratic formalities that were required to begin any legal economic activity. This caused a limited development of private enterprises (so-called privatisation from the bottom up), mainly small private workshops, which in the eighties became the main direction for transformation in the ownership structure of Polish industry (Misztal, 1993).

In 1985 the ownership structure of industrial enterprises in the eastern border provinces of Poland was very similar to the ownership structure in the rest of the country. The dominating part of the industrial labour force was employed in state owned industry (79.0\%), $20.3 \%$ in cooperative enterprises and $0.7 \%$ in enterprises of unidentified ownership.

The second half of the eighties brought with it the development of private small scale industry - not only in the eastern border regions, but throughout the rest of the country as well. This development was caused by a huge demand for consumption goods on the internal market, as well as the low interest rates. Many qualified industrial workers, left the government enterprises and - thanks to the low interest rate - managed to set up their own small workshops, which were more involved in production than in providing repair services. Some of the enterprises had an automated production process and due to comparatively higher wages, they had relatively no problems with worker recruitment.

A new direction of industrial privatisation accepted by the government, was the creation of foreign small scale industries. Until 1982, such enterprises were known as "Polish-foreign" enterprises, as their owners were usually citizens of other countries but were of Polish descent. Such foreign firms played only a small role in the privatisation of industry in Poland as a whole, and an even smaller role in the eastern provinces.

The legal basis for creating mixed companies with private foreign capital, known as 'joint ventures', has already existed since 1986. The foreign small scale industries mentioned above, readily transformed themselves into such enterprises. However, the first such industrial joint venture, came into existence only in 1988. Until 1991, joint ventures, which usually had the legal status of the limited company, did not play a serious role in the privatisation of Polish industry, especially in the eastern border regions (Misztal, 1993).

The legal basis for privatisation was actually only created in 1990 according to the act of the 13 July 1990 which foresaw the privatisation of state-owned enterprises and the creation of the Ministry of Ownership Reconstruction. The Minister for Ownership Reconstruction, was responsible for indicating which state industries were meant for privatisation. At the same time, due to the amendments made to the civil code in 1990 , the concept of the public sector according to Polish law - stopped existing. This resulted in cooperative enterprises, foundations, social and political organisations as well as labour unions being incorporated into the private 
sector. The above decisions caused fundamental changes in the ownership structure of industry. The process of economic transformation, which was occurring at the same time, forced all enterprises to restructure and rationalise their labour force, adding to the increase in unemployment.

As a result of privatisation, the ownership structure of industrial enterprises from 1985 to 1997 entirely transformed itself. The industry of eastern provinces in 1997, was dominated by the private sector, which concentrated $71.4 \%$ of all workers employed in industry (Dziakowska, Osiński, 1999).

The privatisation in the weakly industrialised regions of the eastern part of the country, took on a somewhat different character to privatisation in the more industrialised regions. In the latter areas, the dominating form of ownership transformation in industry was so-called capital privatisation, whilst in the former regions - including the provinces forming the "Eastern Wall" - this involved the liquidation of state owned industrial enterprises.

\section{THE SIZE STRUCTURE OF INDUSTRIAL ENTERPRISES}

The most commonly used criterion in determining the size of an enterprise, is the number of employees (Wielonski, 1996). In this study, five different size groups of industrial enterprises are assumed. Businesses employing at least 500 people are termed as large, enterprises employing 100-499 people are classed as intermediate, from 10 to 99 workers - as small and below ten workers - as micro-enterprises. The micro-enterprises were further divided into two groups: those employing up to four workers are termed as family micro-enterprises and those employing from 5 to 9 people as larger micro-enterprises.

In the eastern border voivodships in 1985 , similarly to the rest of the country, the highest employment was in large industrial enterprises. These employed 103.6 thousand workers, which represented $42.2 \%$ of the total labour force employed in industry. This was due to the preference of socialist planners for very large industrial plants, which in turn tied in to expectations of increasing returns to scale (decreased unit costs of production). 78.9 thousand people $(32.5 \%)$ were employed in intermediate industries, and in the small ones 51.1 thousand $(21.0 \%)$. The micro-industries - especially the family ones - were only of a marginal importance. They employed only 5.6 thousand people (2.3\%) and 3.6 thousand people (1.5\%) respectively. In comparison to the rest of the country, the share of small enterprises, intermediate enterprises and micro-industry in employment was relatively higher $(57.8 \%)$, which was the result of the limited importance of this region in the industrialisation policy of the country, rather than in the recognition of the importance of such industrial units.

From 1985 to 1997 , various positive changes in the structural size of industry in the studied region took place. Although employment in industry decreased by 54.6 thousand people $(22.5 \%)$, the decrease in employment 
only occurred in large enterprises - 32.9 thousand people (by $31.8 \%$ ), intermediate enterprises - 20.2 thousand people $(25.7 \%)$ and small enterprises -15.6 thousand people (by $30.5 \%$ ). Employment however, rose in the micro-enterprises, by 12.9 thousand people in the family industries - a fourfold increase of $360.2 \%$ - and by 1.3 thousand people $(24.0 \%)$ in the larger micro-industries.

Despite the positive structural changes that took place, the situation in this respect is still far from satisfactory. In 1997 the highest employment was still in the large enterprises - almost 37.6\%. A somewhat smaller employment occurred in the intermediate and small industries $-31.1 \%$ and $18.9 \%$ respectively but the smallest employment was in the micro-enterprises - $12.4 \%$. In comparison to 1985 , the share of family micro-enterprises in total industry rose considerably to $8.7 \%$, whilst the share of larger micro-enterprises rose by a more modest $3.7 \%$. However, the share of the other groups in industry decreased.

The substantial rise in employment in the smallest enterprises was associated with 'founder' privatisation (so-called bottom up privatisation), based on creating completely new firms. Very often these are family-industries producing clothing, furniture or shoes. The sharp rise in the number of micro-enterprises serves as proof of the ever growing popularity of this form of industrial privatisation, but at the same time of the difficulties facing new firms - at the first phase of economic transformation - in obtaining capital, which disenables them to develop their businesses onto a somewhat greater scale.

\section{THE BRANCH STRUCTURE OF INDUSTRY}

The socialist policy of industrialisation did not promote a modernisation of the industrial structure. Its main concern was the creation of means of production. An ever increasing technological gap was continuing to develop between Polish industry and the industry of highly industrialised countries. Although attempts at partial reforms in the eighties, created new conditions for the functioning of industrial enterprises, which became economic units that were: independent, self-controlled and self-supporting, they did not lead to changes in the branch structure of industry.

In 1985 the largest number of people (25.2\%) were employed in the electromechanical sector, which was essentially one the most modern sectors at the time. There was also a high employment in light industry $(20.1 \%)$ and the food processing industry (19.6\%). An important role was also played by the mineral (11.1\%) and the wood-pulp (11.0\%) industries.

From 1985 to 1997 the highest decrease in employment - in absolute values - occurred in the electromechanical sector, a fall of 34.3 thousand employees (or 56.1\%), in light industry - 12.7 thousand people (or $26.1 \%$ ), the mineral sector - 11.3 thousand people (or 41.9\%) and the wood-pulp 
industry -6.9 thousand people (or $25.7 \%$ ). Thus the most significant declines occurred in the sectors that played the most important role in the industrialisation of the region.

In 1997 the largest employment was in the food processing industry (23.2\%), light industry (19.1\%), the electromechanical sector $(14.2 \%)$ and the wood-pulp industry $(10.6 \%)$. There were significant changes in the structure of industrial sectors in all the voivodships. The electromechanical industry did not remain the most significant industrial sector in any of the voivodships. In 1997, the main source of employment in the seven studied voivodships was the food processing industry in three of the voivodships, and light and chemical industry in the other two.

The decrease in the employment in the electromechanical industry was the result of the liquidation of factories, and in the decrease of employment. These industries were usually the affiliates of enterprises from larger industrial centres such as Warsaw, which produced goods for the markets of the member states of the Council for Mutual Economic Assistance (Comecon). It was however, the traditional industries that best adapted themselves to the new conditions, taking advantage of the local production potential and the local market e.g. the food processing industry. These industries, which were mostly quite small, were more elastic in adapting themselves to the production profile of the new economic environment.

\section{SUMMARY}

The number of employees working in industry in the eastern border voivodships from 1985 to 1997 , decreased by a similar degree as in the rest of Poland, which in effect did not influence the change in the disproportion in industrialisation of the studied region and the country.

The greatest and most positive changes occurred in the ownership structure. They were based on an increase in the employment in the private sector. In the second half of the eighties the changes in the ownership structure of industry were relatively small and they were only accelerated in the nineties, after the passing of the act involving the privatisation of state owned enterprises.

From 1985 to 1997 the number of workers employed in large, intermediate and small enterprises decreased, whilst a large increase was apparent in the micro-enterprises. The changes in the size structure, based on the limiting of the role played by large industries in favour of the smaller industries, should also be viewed as a positive result. What is less favourable however, is the decrease in employment in intermediate and small enterprises. Without a doubt, a very positive occurrence is the development of many micro-enterprises, headed by private individuals. Yet, unfortunately these are enterprises with a very limited production potential, and many are facing imminent liquidation. 
Changes in the structure of industrial sectors, were mainly due to the decline in the role played by the most important and most modern industry in the border regions, i.e. the electromechanical industry. Although in comparison to economically developed countries, this was an industry with a relatively low technical standard, it belonged to the most modern branch of industry in Poland. A large decrease in employment also occurred in mineral, wood-pulp and light industry whilst only a relatively small change in employment occurred in the food processing industry. As a result of this, the food processing industry became the most important enterprise of the studied region, managing to outskirt the electromechanical and light industry. The electromechanical industry did not play the most important role in employment in any of the studied voivodships in 1997.

The structural changes of industry in the eastern border regions - as in the rest of the country - are contrary to the characteristic tendency shown by developed countries and they are based on a decrease in participation of progressive sectors of industry, and the increase in the participation of traditional industries, allowing a rise in production without significant capital outlay. The positive changes in the ownership structure of industrial enterprises and to a lesser degree the size structure, have not - as up till now - been reflected in any profitable changes of the structure of the industrial sectors and they depend on the rise of importance of traditional branches of industry, and limiting the role played by modern industries.

To sum up it can be said that the eastern border provinces experience almost all the problems and shortcomings of industrial development, which are characteristic for the rest of Poland as well as other local problems resulting from the historic neglect and underdevelopment of this region. From the point of view of industrial development, it is still to early to tell whether this region can be definitely treated as the "Eastern Wall" or possibly the "Eastern Zone of Economic Activity". This can be said, as from 1985 to 1997 there was a only slight rise in the regions participation in the total industrial employment of the country and in the value of its capital goods, whilst at the same time there was a decrease in its participation in total industrial investment and, what is most worrying, in the value of goods sold. The rise in economic activity of the eastern border regions relates to services rather than production.

\section{REFERENCES}

Dziakowska H., Osiński S., 1999, Zmiany strukturalne w przemyśle wschodnich województw przygranicznych Polski w latach 1985-1997 [Structural changes in Poland eastern border voivodships from 1985 to 1997] [in:] Horodeński R., Rościszewski M. (eds), Wschodnia strefa aktywności gospodarczej [The eastern zone of economic activity], Wydawnictwa WSE, Białystok, 153-204.

Horodeński R., R ościs zew ski M. (eds), 1999, Wschodnia strefa aktywności gospodarczej [The eastern zone of economic activity], Wydawnictwa WSE, Białystok. 
Misztal S., 1993, Regionalne zróżnicowanie procesu prywatyzacji przemysłu w Polsce [Regional differentiation in the process of privatisation in Poland], Przeglad Geograficzny, LXV, 3-4, 255-277.

Mokrzyc M., 1998, Funkcjonowanie specjalnych stref ekonomicznych w Polsce [The functioning of special economic zones in Poland], Gospodarka Narodowa, 8-9, 1930 .

Rościs zew ski M., 1997, Polska granica wschodnia [Poland's eastern border], Geopolitical Studies, 1, IG PAN, Warszawa.

Rośc is zew ski M., 1999, Uwarunkowanie geopolityczne Wschodniej Strefy Aktywności Gospodarczej [The geopolitical conditioning of the Eastern Zone of Economic Activity] [in:] Horodeński R., Rościszewski M. (eds), Wschodnia Strefa Aktywności Gospodarczej [The eastern zone of economic activity], Wydawnictwa WSE, Białystok, 23-63. S

Wieloński A., 1996, Rola przemysłu drobnego w restrukturyzacji gospodarki Polski [The role of small scale industry in the restructuring of Poland's economy], Prace i Studia Geograficzne, 8, Wydawnictwa UW, Warszawa, 25-33. 